\title{
Landscape formation, environmental changes and prehistoric occupation (Jacaré-Guaçu River Lowlands, Araraquara area, Southeast Brazil, Late Pleistocene-Holocene interval): correlation between geomorphological, pedological, geochronological and archaeological data
}

\author{
Formação da paisagem, mudanças ambientais e povoamento pré-histórico \\ (Terras Baixas do Rio Jacaré-Guaçu, Área de Araraquara, Sudeste \\ Brasileiro, Intervalo Pleistoceno Tardio-Holoceno): correlação entre \\ dados geomorfológicos, pedológicos, geocronológicos e arqueológicos
}

\author{
Pedro Michelutti Cheliz ${ }^{\text {ab }}$, Regina Celia Oliveira ${ }^{\text {ac }}$
}

aUNICAMP

bpedro.michelutti@gmail.com, ${ }^{c}$ reginacoliveira@ige.unicamp.br

\begin{abstract}
This paper presents a geomorphological, pedological and geochronological characterization and contextualization of geomorphogenetic, chronomorphological and environmental sequences from the Araraquara area (central São Paulo State, Southeast Brazil), and their relationship to lithic material from hunter-gatherer archaeological lithic sites. A special emphasis is given to a detailed study of the lowlands of the Jacaré-Guaçu River (between the cities of Araraquara and Boa Esperança do Sul, São Paulo state, Brazil), near the Boa Esperança II hunter-gatherer archaeological site, BES II, in an area of clear asymmetry of the alluvial plain and adjacent slopes. Data derived from the survey of estimated morphogenetic and environmental dynamics are used to contextualize the archaeological material of the BES II site, which is discussed as being associated with the Pleistocene-Holocene transition (an unusual occupation age for the Brazil southeast). We pointed to alternation between successions linked to a quaternary manifestation of a longer pattern of changes of lateral flatting processes and stability of base level with others linked to vertical incision and adequacy to a new base level. We propose a geomorphological model for the Lowlands of Jacaré-Guacu River, highlighting the possibility that the asymmetry of the plain would be linked to a wider heterogeneity of its geomorphological context of semidetails, partially correlated with the overlapping of neotectonic influence and environmental fluctuations. It is suggested that data from the physical environment of the above mentioned lowlands are compatible with absolute ages obtained by OSL (lower terrace Ia, $14,500 \pm 3000$ years BP, basal gravel level of the surface coverings, to $10,900 \pm 1500$ and $4090 \pm 340$ years BP at the sandy soils and sediments above the gravel) and ${ }^{14} \mathrm{C}(8630$ years BP, at the level of gleyed sandy-clay soil of $120 \mathrm{~cm}$ deep of the low terraces IIa) on archaeological levels of the low terraces of the Jacaré-Guaçu river, in a context of climatic transition from semi-arid conditions to higher humidity, hydrological changes (ephemeral and torrential channels changing to oscillating regimes of perennial channels, with sets of meanders of variable widths of paleochannels, suggesting climatic changes related to the modifications of the fluvial patterns), successive fluctuations $(<10 \mathrm{~m})$ of base levels and large $(500 \mathrm{~m})$ lateral migration of the main river to the north guiding the local chronomorphological successions between Late Pleistocene and Late Holocene. The landscape and fluvial dynamics changes over time has influenced the availability of attributes needed for the hunter-gatherer lifestyle (such as fluctuations in the deposition/exposure of river pebbles used as raw material for tool making). Those oscillations are presented as a contribution to explain alternation between more and less dense archaeological levels along the vertical cuts of the low terraces and the location of exception of the BES II site (installed on a fluvial plain and low terraces in a segment characterized by the rarity of rocky outcrops, while most sites in the Araraquara area are linked to slopes, proximal to rocky outcrops - primary sources of lithics artifacts making) on the geomorphological Araraquara area context
\end{abstract}

Keywords: Fluvial geomorphology; geomorphologic mapping; pedology; Pleistocene-Holocene transition; lithic archaeologic site

\section{Resumo}

O presente artigo apresenta uma caracterização geomorfológica, pedológica e geocronológica e a contextualização de sucessões geomorfológicas, cronomorfológicas e ambientais da área de Araraquara (centro do Estado de São Paulo, Sudeste do Brasil) e de suas relações com remanescentes humanos líticos de sítios arqueológicos locais associados a antigos grupos caçadores-coletores. Uma ênfase especial é dado a um estudo de detalhe das Terras Baixas do Rio Jacaré-Guaçu (no limite entre os municípios de Araraquara, SP, e Boa Esperança do Sul, SP), próxima ao sítio arqueológico Boa Esperança II, BES II, numa área de clara assimetria da planície aluvial e vertentes adjacentes. A caracterização do meio físico e das dinâmica 
geomorfogenéticas e ambientais são usadas para contextualizar os registros arqueológicos do sítio BES II, o qual se discute de ser associado com o intervalo temporal da transição Pleistoceno-Holoceno (uma idade de ocupação pouco usual para o sudeste do Brasil). Elencamos a alternância de fases em que predominam processos de aplainamento com outras em que prevalecem a incisão vertical e adequação da paisagem a um novo nível de base na área de detalhes, ligadas a manifestações quaternárias de um possivelmente mais longo padrão de geomorfogênese. Propomos um modelo de transformações geomorfológicas da paisagem das Terras Baixas do Jacaré-Guaçu, destacando que a assimetria da planície aluvial teria contribuição de um conjunto mais amplo de heterogeneidade geomorfológicas da área de Araraquara, tendo contribuição da sobreposição de influência neotectônica e de modificações climáticas. Sugere-se que os dados levantados e modelos genéticos da paisagem propostos no presente trabalho mostram-se compatíveis com datas absolutas obtidas por LOE (baixos terraços Ia, $14500 \pm 3000$ anos atrás, nas cascalheiras basais das coberturas superficiais locais, a $10900 \pm 1500$ e $4090 \pm 340$ anos atrás nos solos e sedimentos arenosos sobrejacentes a cascalheira) e ${ }^{14} \mathrm{C}$ (baixos terraços IIa, 8630 anos antes do presente, no nível de solos areno-argilosos de $120 \mathrm{~cm}$ de profundidade) em níveis arqueológicos nos baixos terraços do rio Jacaré-Guaçu, num contexto de transição climática de condições semi-áridas para outras de maior umidade, mudanças hidrológicas (canais torrenciais e efêmeros oscilando para canais perenes, vinculados a conjunto de paleocanais de meandros com larguras maiores do que os atuais, sugerindo mudanças climáticas ligadas com as modificações de padrões fluviais), sucessivas flutuações $(<10 \mathrm{~m})$ de níveis de base e significativa $(500 \mathrm{~m})$ migração lateral do posicionamento do rio Jacaré-Guaçu para o norte caracterizando as sucessões cronomorfológicas locais entre o Pleistoceno Tardio e o Holoceno Tardio. A dinâmica de transformações fluviais e da paisagem influenciaram mudanças ao longo do tempo da disponibilidade de atributos necessários ao modo de vida caçador-coletor (como as flutuações na deposição e exposição de seixos fluviais usados como matéria-prima para a preparação de ferramentas de pedra lascada). Referidas oscilações são apresentadas como uma contribuição para explicar a alternância entre mais e menos densos níveis arqueológicos ao longo dos cortes verticais dos baixos terraços, bem como auxiliam a compreender a localização de exceção do próprio sítio BES II (instalado em planície fluvial e em baixos terraços num segmento caracterizado por raridade de afloramentos rochosos, enquanto a maior parte dos sítios arqueológicas da área de Araraquara vinculam-se a encostas, proximais a afloramentos rochosos - fontes primárias de matérias-primas para confecção de artefatos líticos).

Palavras-chave: Geomorfologia fluvial; mapeamento geomorfológico; pedologia; transição Pleistoceno-Holoceno; sítios arqueológicos líticos

\section{Introduction}

Much has been debated about correlations between geomorphic transformations, environmental changes and past human occupation between Late Pleistocene and Holocene. In São Paulo State (Brazil), the relationship between human occupations and landscape formation during the Pleistocene-Holocene transition (13000 to 8000 years before present - BP) is controversial (Bueno et al. 2013). The findings and dates from lithic site Alice Boer (Rio Claro, São Paulo), which demonstrated such a relationship, were viewed with reservations in the context of the data, and recently re-studied (Feathers \& Araújo 2016, Araújo et al. 2017). Thus, most of the occupation models for eastern South America consider the interior of São Paulo as one of the most recent areas of occupation, with migrations from both north and south (Bueno et al. 2013). Santos (2011) obtained a date from another lithic site in the interior of São Paulo (near the limit between the cities of Araraquara and Boa Esperança do Sul) - the BES II archaeological site - consistent with the Pleistocene-Holocene transition. The same author also drew attention to the relatively small number of dates in lithic sites in the interior of São Paulo.

In the following years, new work also focused on the chronological importance of lithic sites in the interior of São Paulo, making it possible to insert the area into earlier timeframes for human occupation (Troncoso et al. 2016, Araújo \& Correa 2016).
In this context, we present the archaeological findings of the area of Araraquara, located in the geographical center of the state of São Paulo where the BES II site, studied by Santos (2011), is inserted (figure 1).

The area contains dozens of archaeological lithic sites and recorded lithic occurrences. Among this set of archaeological material, some of the sites have elements to suggest their insertion into the context of the Pleistocene-Holocene transition.

Among the precautions and procedures recommended for the discussion of sites ages, their contextualization and relationship with the physical environment are included in semi-detailed and detailed scales of analyses. It is often found that the local physical environment harbors elements that question the dating obtained by various analytical or relative procedures. For instance, erosive remobilization of the archaeological material itself was highlighted in discussions involving the Abismo da Flecha site in the Ribeira Valley and its possible correlation with the Pleistocene animal bones (Prous 1992). Other doubts concern whether materials collected for dating are in fact concomitant with human occupation. Bueno et al. (2013) points out that contextualization and interfacing with the physical environment is particularly relevant for the validation of absolute dates as effective ages of past human occupation, but considers that it is commonly relegated to the background and not carried out. As a contribution in this direction, this text seeks to present elements of the physical environment of the 
Araraquara area lithic sites - with special focus on the contextualization of BES II - with regard to their relationship with estimated geomorphological and environmental changes over time. The data and discussions presented here were developed during the author's undergraduate dissertation and are also part of his doctoral research which is still in progress, forming part of a series of geomorphological and archaeologic research (Cheliz 2010, 2012, 2015, 2016, Cheliz \& Oliveira 2011, Santos 2011, Santos \& Cheliz 2017) on the Lowlands of Jacaré-Guaçu River of Araraquara area.

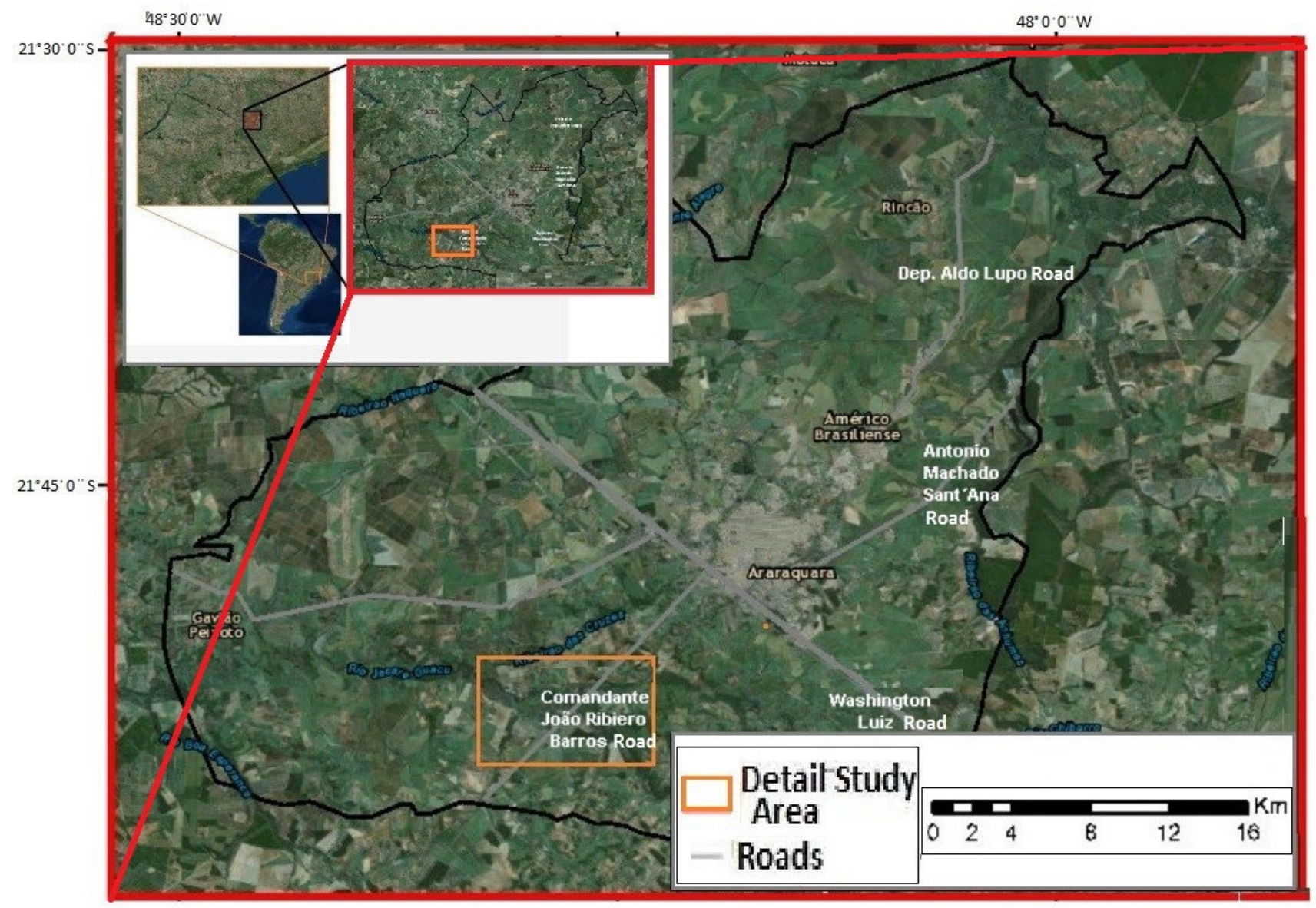

Figure 1: Location of the study area (black line) and detailed study area (orange line). Source: Google Earth

\section{Methods}

A series of different procedures were used to survey attributes of the local physical environment in the semidetail and detail analysis scales. Both scales were subsequently integrated to avoid the segmentation of the research and allow more holistic interpretations.

Initially a bibliographic review of the study area was carried out, followed by geological and morphometric mapping procedures. These materials resulted in the Geological, Altimetric and Clinographic charts needed to mark the level of analysis of the Relief Compartmentalization (Ab'Saber 1969). These procedures were carried out by integrating field mapping activities with around 190 descriptive field points arranged along the study area, with analysis of aerial and orbital images (Gigliotti 2010). The Relief Compartmentalization Chart was composed based on the overlap of the listed data. All the above cartographic materials were elaborated in a scale of 1:70000.

We also inventoried lithic archaeological sites of the region, protected by the Museum of Archaeology and
Palaeontology of Araraquara (MAPA), with emphasis on recording some of their key characteristics and location. After completing these procedures, we attempted to analyze and discuss the distribution of the sites, their attributes and their insertion within the relief compartments surveyed in the previous stage - from the point of view of the objectives of the present study.

After this set of surveys, an area that were considered of special interest for understanding the mechanisms responsible for chronomorphological succession has been chosen. These correspond to the valley bottom of Jacaré-Guaçu river where records of the surface structure linked to the Cenozoic dynamics of Araraquara area (surroundings of the site BES II) are better preserved. Here, we carried out detailed subdivisions of the relief at a scale of 1:25000, as well as a survey of pedosequences, and inserted the archaeological register within relief tables using the concept of Structural Analysis of Soils (Queiroz Neto 2002) with a set of 30 auger wholes. This process took into account the distribution of the archaeological material over horizontal and vertical space. The second set of procedures studied the soil 
structure and integrated work carried out with Santos, Ladeira, Araújo, Rodrigues and Santos between 2010 and 2017 - including new Optical stimulated luminescence (OSL) and ${ }^{14}$ Carbon dates from new excavations units on the low terrace of BES II site and Jacaré-Guaçu River. A second discussion was made at the end of this second set of studies that sought to link the procedures used and compare them with results obtained at the semidetailed level for better contextualization.

\section{Results and discussion}

\subsection{Physical environment of the Araraquara area}

The Araraquara area is located in inland escarpments (cuestas) of the Paraná Sedimentary Basin (Almeida 1964), which Mano (2006) describes as being the portal to the historical indigenous region known as Campos de Araraquara. This is an area where rocks of the São Bento Group, after rising to an altitude of $800-1100 \mathrm{~m}$ in the steep cliffs of São Carlos, Rio Claro and Itaqueri (to the east and northeast), decline in height and soften their slopes to hide beneath the sediments of the Bauru Group. Here, rocky clusters in the form of extensive smoothed levels appear on discrete slopes surrounding semiflattened highlands, intersected by numerous river valleys of limited vertical gradients.

The interface of the rocky units with the ground surface is such that the former correspond to relatively well individualized relief patterns. The local geological map provides good preliminary indicators of the distribution of the major regional relief partitions (see figure 2 and 3). The sandstone outcrops of the Botucatu Formation and the soils derived from them originate rise in the valley bottoms of regional rivers. There are sometimes difficult to differentiate from quaternary alluvial sediments, especially in the northwest and southeast of the area, and at the base of the cliffs bordering the great valleys (Meaulo 2007, Cheliz 2016). The mafic rocks of the Serra Geral formation are generally arranged east-west in intermediate topographic segments, and in the northeast-southwest direction in the segments that contain springs, in higher topographic levels. In turn, the areas associated with the sediments of the Bauru Group are placed in the tops of valleys and in the most well individualized ridges

The Araraquara area is under subtropical conditions, which are characterized by hot and rainy summers (average temperatures above 23 degrees, and monthly precipitation above $200 \mathrm{~mm}$ ) and dryer conditions in autumn and winter (monthly precipitation usually under $60 \mathrm{~mm}$ ). Oscillations in rainfall throughout the year are not enough to compromise the permanence of relict fragments of diverse cerrados, vegetation associations, nor to compromise the perennial character of the hydrographic network. The numerous springs and streams that flow from higher altitudes, as well as the great valley bottom rivers that cross the area (Jacaré-Guaçu and Mogi-Guaçu) flows continuously throughout the year.

While assessing the overlap of the rocky units with slope and altitude patterns, we noticed a tendency to attenuate more salient relief contrasts. When approaching the area during the day by conventional routes, the impression is that of increasing homogeneity in the physical geography. When arriving from the southeast by the Washington Luiz highway, after crossing the imposing eastern Cuesta, the morphological features of the landscape begin to smooth, and contrasts diminish. Great altimetric breaks witnessed only a few dozen miles before give way to minor local vertical gradients. Local slopes are mostly contained below 10 degrees, and altimetric gaps do not exceed $250 \mathrm{~m}$ between the valley bottoms of the Jacaré-Guaçu and Mogi-Guaçu rivers and the ridges of the area. The general aspect of apparent increasing monotony and homogenization seems at odds with a study aimed at detailing the geomorphic attributes of this region.

However, the overlapping of the three datasets lithological, altimetric and clinographic - allows us to identify subtle internal heterogeneities in the geomorphology which have possible relations to site distribution and lithic occurrences.

\subsection{Semi-detail level data}

Based on the weighted overlap of morphometric and lithological data, we can suggest three large relief compartments linked to the Araraquara area. They are the Lowlands of Jacaré-Guaçu and Mogi- Guaçu, the Transitional Levels and the Highlands and Residual Plateaus (figures 2, 3, 4 and 5).

Their characteristics are the following:

The Highlands and Residual Plateaus (660-710 m) encompass associations of geomorphological patterns of smoothed slopes and divisors, which correspond to the ridges of this interiorized segment of the basaltic escarpment. Its highest areas are marked by extensive flattened and semi-flattened terrains linked to sandy coverings that extend for up to half to dozen kilometers. The most elevated of these surpasses the altitude of $700 \mathrm{~m}$ in a segment arranged in W-E direction between the municipal headquarters of Américo Brasiliense and Santa Lucia, from which it dismembers into numerous secondary ridges running NW-SE. From the edges of these flattened highlands, the altitude of the terrain decreases to form discrete slopes that look for the basaltic beds of the perennial streams that flow subparallel, in a NW-SE direction. 


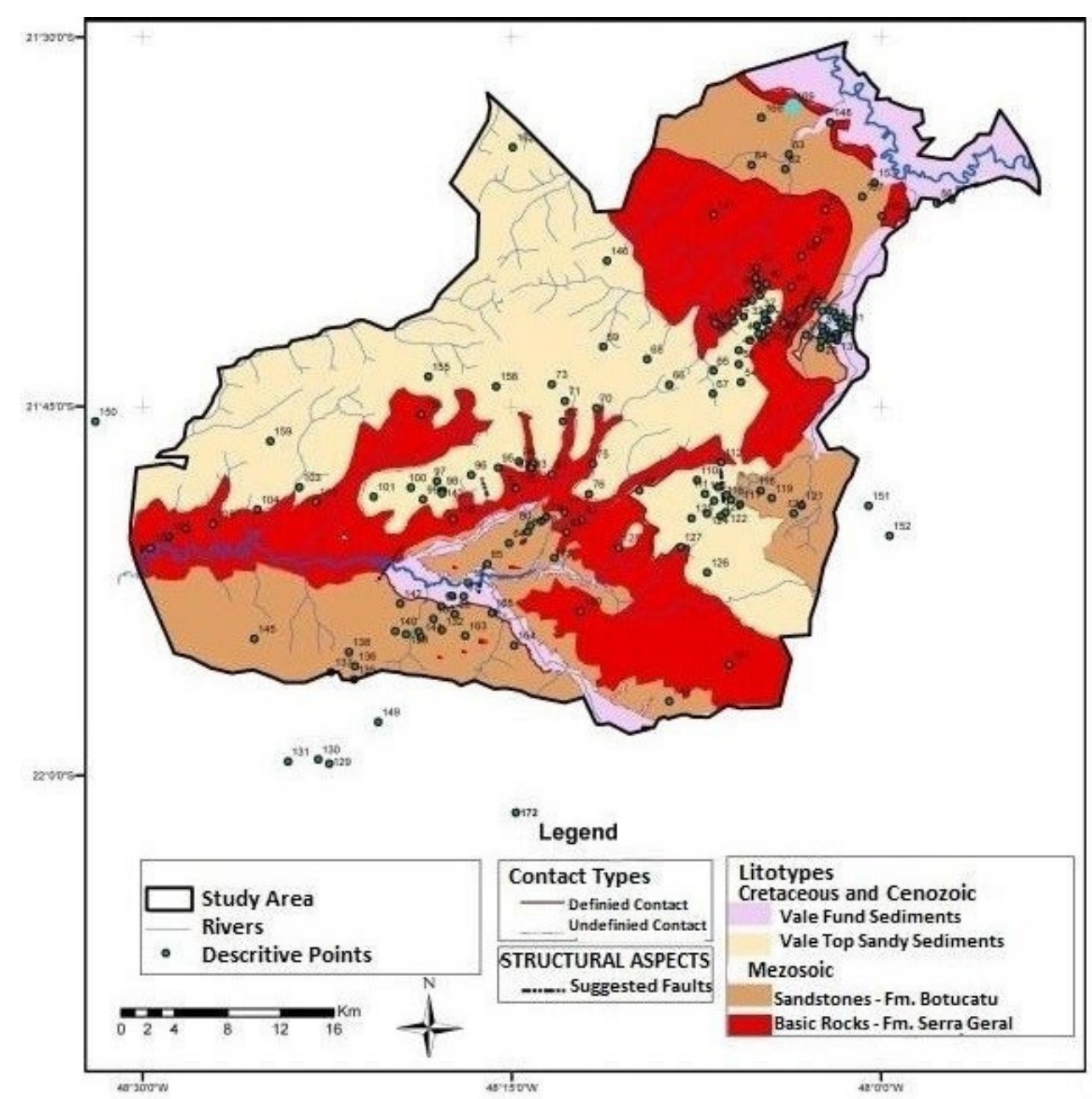

Figure 2: Geologic map (draft) of Araraquara area. Source: adapted from Cheliz (2016)

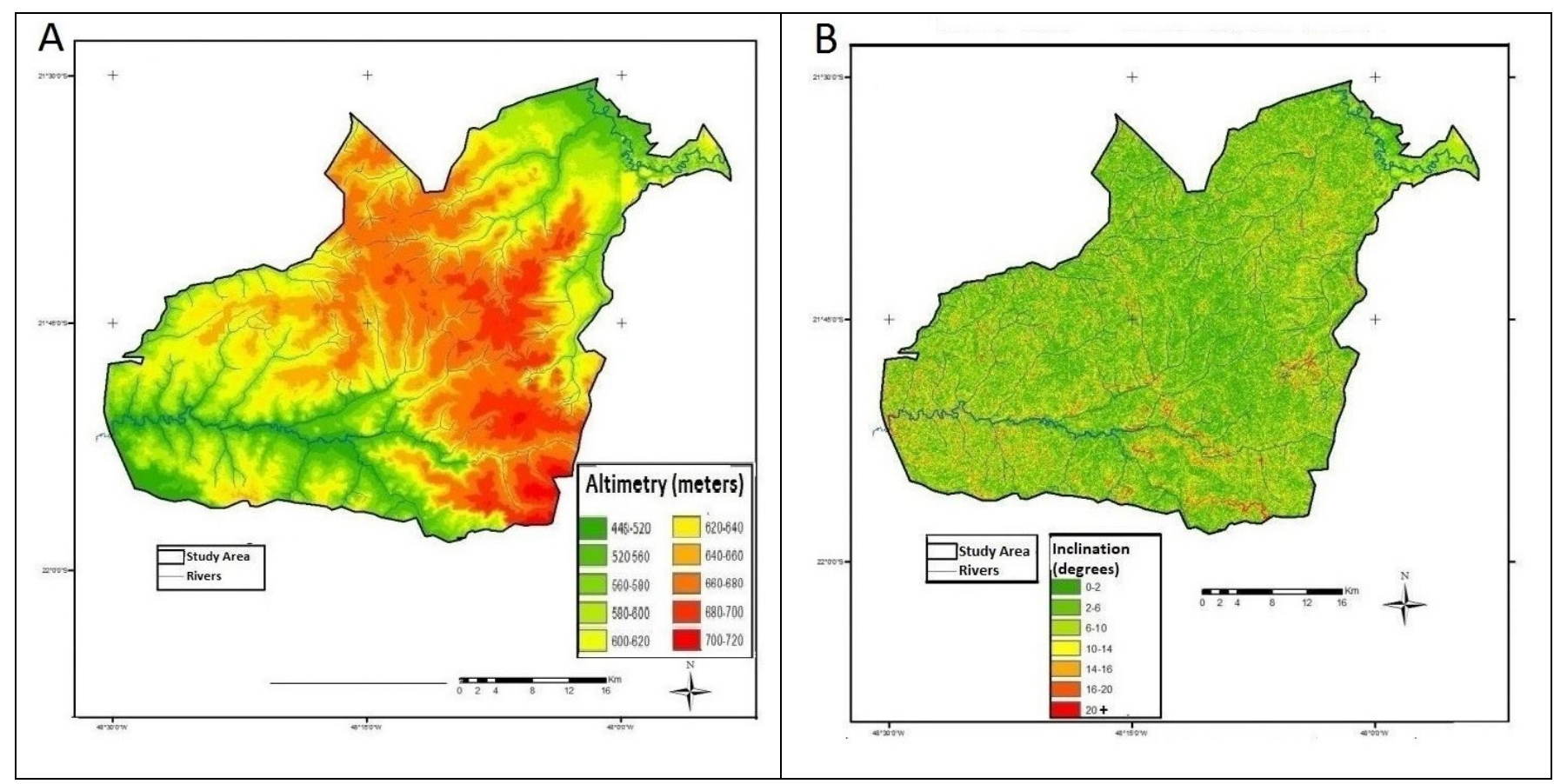

Figure 3: (A) Altimetric and (B) declivity maps of Araraquara area. Source: adapted from Cheliz (2016)

Despite the fact that the Residual Plateaus are the most extensive compartment in the area, there are no known lithic archaeological sites in these areas. The compartment, however, concentrates the pioneer 
agropastoral villages and coffee plantations of the historic period. These locations also account for most of the urban spots of the area.

The Transitional Levels $(530-660 \mathrm{~m})$ is a compartment consisting of a series of slopes (with inclines predominantly between 5 and 30\%) and channels with different types of edges covering those similar to embedded channels sectioned by terrains approaching $90^{\circ}$ to others with softer patterns (figures 3 and 5).

It covers the widest altimetric range of the study area, and has some segments that reach up to $730 \mathrm{~m}$. Lithographically, it is considered to contain the geological contact between mafic rocks of the Serra Geral Formation and the clastic sandstone rocks of the Botucatu Formation.

The transitional levels concentrate the majority of archaeological sites in the study area, which are evidenced particularly next to the areas of larger inclinations. The presence of diversified artifacts (figures 4 and 5) crafted from sandstone is noteworthy (Schiaveto 2007, Cheliz 2015, 2016).

Of the 26 lithic archaeological sites and occurrences documented in the area, about 24 of them are located in the middle of the Transitional Levels, including six of the eight lithic sites.

This relief unit is distributed contiguously between the Highlands and Lowlands of ancient Araraquara, and is thus a unit of transition between the two geomorphic patterns. The horizontal extent of the Transitional Levels perpendicular to the boundaries with the two adjacent compartments is variable. In some segments, the

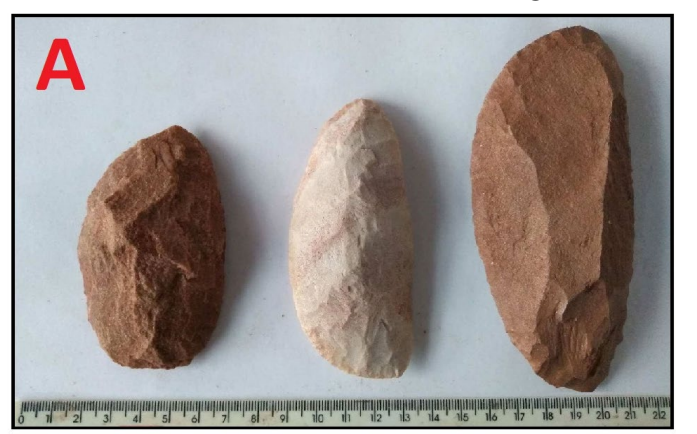

Transitional Levels extend to almost $8 \mathrm{~km}$, and rarely less than $2 \mathrm{~km}$. Their slopes are divided into low and medium slopes (between 4 and $12 \%$ average inclination), high slopes (between 12 and $30 \%$ average inclination), and Brushed Escarps, with continuous inclinations extensions greater than $30 \%$.

The proportion between these sets of slopes regulates the horizontal extension of the compartment itself, with the most extensive segments usually being dominated by low and medium inclination, and the leanest by those with a high inclination. It should be noted that rocky outcrops (sandstone and basalts) appear to be more common in the minor segments of the compartment, where high slopes predominate.

The basalt outcrops are sometimes truncated by multiple families of joints, some of which are filled by silica-rich veins.

In some of these high slope segments or next to them, lithic archaeological sites and associated artifacts of silicified sandstone are concentrated (sites Gavião Peixoto, BES I, BES III and Rainha dos Montes).

The Lowlands of the Jacaré-Guaçu and Mogi- Guaçu $(480-530 \mathrm{~m})$ are characterized by the alternation of large fluvial terraces, flood plains and smoothed slopes, as well as by occasional residual hills. They are mostly found between 485 and $530 \mathrm{~m}$ adjacent to the Jacaré-Guaçu and Mogi-Guaçu rivers, and some of their tributaries. Lithographically, they combine sandstones from the Botucatu Formation and predominantly alluvial, sandy sediments.

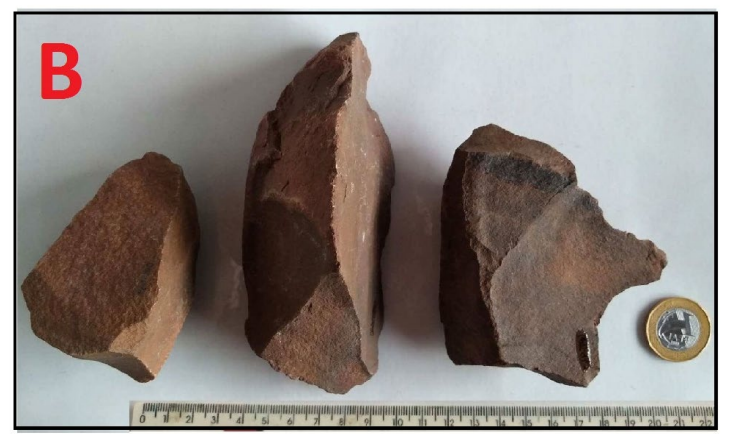

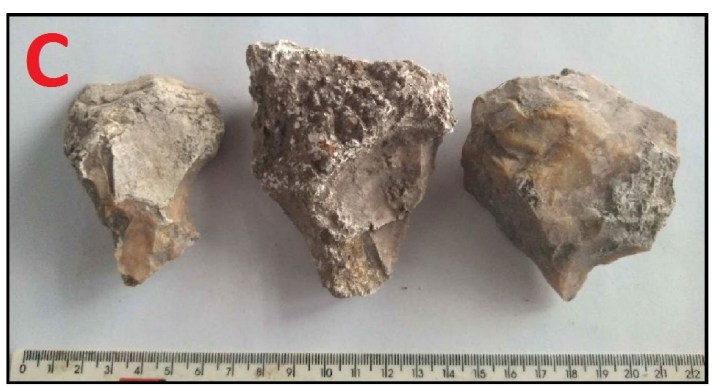

Figure 4: Archaeological lithic artifacts from Araraquara area: (a) sandstone artifacts from Rincão I site, (b) sandstone artifacts from Gavião Peixoto II site, (c) chert artifacts from Boa Esperança II site.

The horizontal extension of the compartment, when considered extents perpendicular to its rivers, varies considerably. There are segments that reach kilometers in extension, and others that do not exceed hundreds of meters. There is a tendency for the compartment segments bordering the main fluvial streams of the Mogi-Guaçu and Jacaré-Guaçu rivers to present the broader extensions..In its larger segments, the Lowlands that border the courses of the main rivers can reach up to more than $5 \mathrm{~km}$ in extension, transverse to the course of the rivers. Meanwhile, side channels occupy attitudes close to $485-500 \mathrm{~m}$ where bed inclination rarely exceeds $3^{\circ}$ (although some segments of the Jacaré-Guaçu river present greater slopes). In the 
segments bordering the tributaries of the main rivers in the Lowlands, the extension of the compartment narrow and slightly higher slightly higher altitudes and greater slopes are recorded

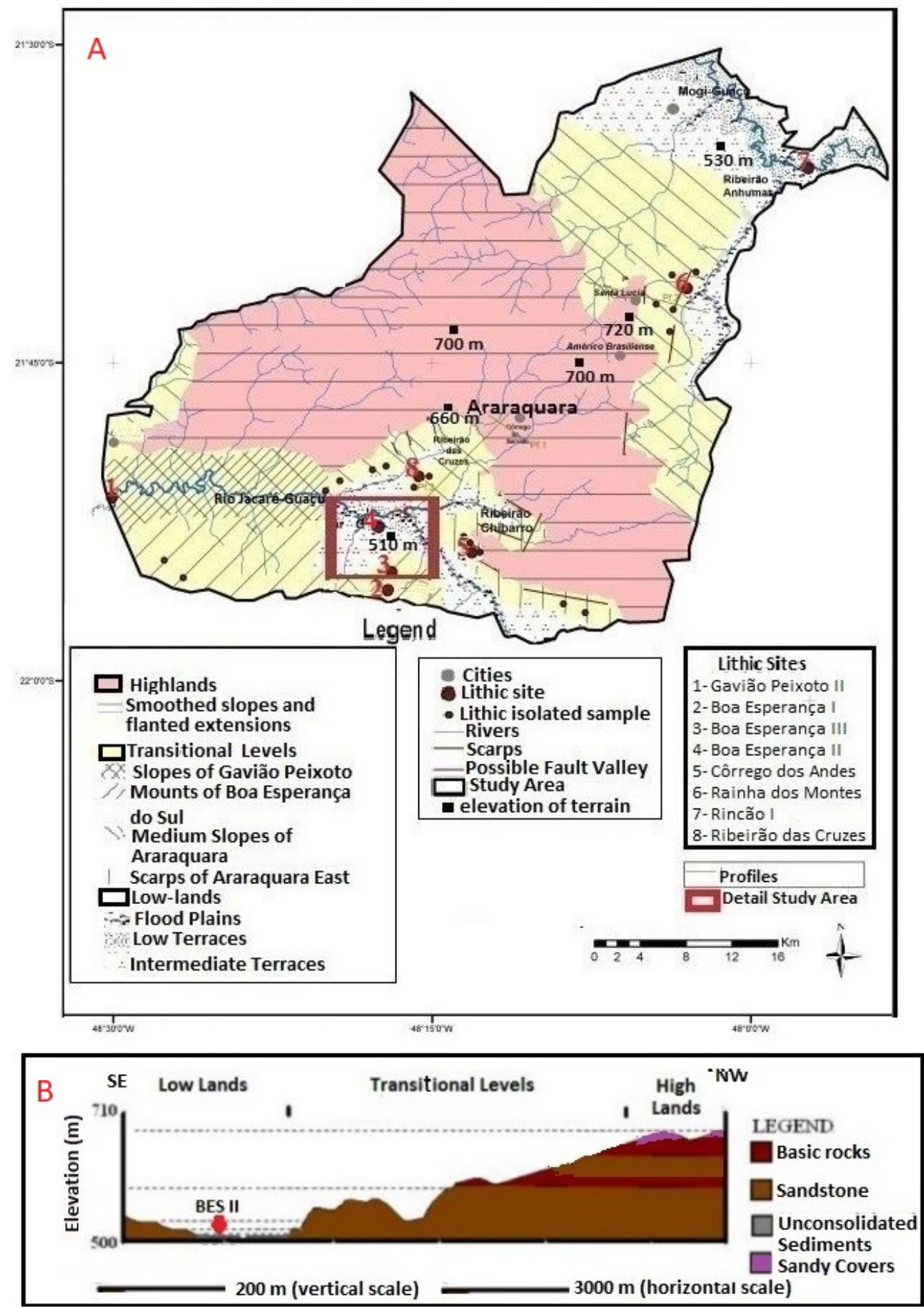

Figure 5: (a) Partition of Relief and distribution of archaeological lithic materials map and (b) geomorphological profile of the area. Source: adapted from Cheliz (2016).

The distribution of archaeological sites in these areas can be observed in figure 4 and consist mainly of sites with quartz and chert artifacts, with sandstone having a secondary role. Among the lithic sites, only Rincão I and Boa Esperança II are located in the Lowlands.

\subsection{Discussion of semi-detail level data}

The patterns described for the relief compartments can be used in initial discussions regarding the relationship between the archaeology and estimated geomorphic sequences of ancient Araraquara. It is suggested that the geomorphogenesis of the area would have included alternating episodes of predominantly lateral flatting 
processes that results in the flat levels documented among the relief partitions (the highest of them at $700 \mathrm{~m}$ and the lowest at approximately $480 \mathrm{~m}$ ), and vertical incision and adaptation to a new base level of indistinct climatic or tectonic origin (at least partially intensified by faults with a restricted distribution of potentially neotectonic character, represented by some of the embedded channels and abrupt escarpments of the Transitional Levels - e.g. near the Rainha dos Montes site).

We believe that the interface between chronological geomorphologic formation and the distribution of lithic archaeological sites in Araraquara can be analyzed under two different viewpoints.

Initially, it is possible to separate sites for which associations cannot be made between human occupation and the alternation of phases of geomorphological formation. Secondly, one can separate sites where human occupation would have been contemporary with alternations between the different geomorphological mechanisms mentioned above.

Among the first, we can mention numerous sites on the Transitional Levels, especially those located in or next to abrupt escarpments (Gavião Peixoto II and Rainha dos Montes).

Although we currently cannot say where their occupation date is close to, or concomitant with, the possible faults to which these cliffs are associated, it is possible to discuss elements linked to local geomorphic attributes that help to understand the distribution of the sites.

It should be remembered that sources of water supply are common to all the relief partitions of the area, although there is a decrease in the flow of the main rivers and streams in the winter months.

The flat terrains, often mentioned as conducive to hunter-gatherer occupations, are, on the other hand, more common in the Lowlands and Highlands.

The availability of rocky outcrops, particularly of sandstones which were preferred raw materials for the Transitional Levels archaeological sites, is significantly higher in the Transitional Levels, and rarer (due to the lesser inclination of the terrain that favors percolation of rainwater and, thus, alteration of the rocks into deep soils) in the Lowlands and Highlands. It should also be noted that in the abrupt escarpments of the Transitional Levels we find with more frequencies in the outcrops centimetric fractures in the form of joint families, commonly associated with spheroidal exfoliations and quartz or silex veins - possible complementary sources of raw material (and present in minor quantity among artifacts of the Gavião Peixoto II site - Scientia 2009, Cheliz 2015). It should be noted that in some of the sites the pieces with a greater complexity of elaboration and retouching were made on raw materials with more restricted availability (Cheliz 2016).

The Boa Esperança do Sul II site (BES II), particularly, is a site with an exception location in the geomorphological context of the Araraquara area. Most sites and lithic occurrences do not appear to be associated with the valley bottom compartment, with the BES II site being one of only two sites located in the Lowlands. This site not only presents the best possibility of dating human occupations in the area, but also where one of the greatest quantity and diversity of lithic archaeological materials that have been found in Araraquara area (Santos 2011, Santos \& Cheliz 2017). The large quantity of lithic instruments - around 2000 artifacts - is interesting because rocky outcrops are not visible on the site and its immediate surroundings. Further and more detailed data collection and mapping is needed in order understand the exceptional location of this site within its geomorphological context, and its link to the geomorphological and environmental changes of the area.

\subsection{Detail level data}

The area selected for detailed study is in the southwestern segment of the Lowlands of Jacaré-Guaçu (Cheliz 2011, 2016, Cheliz \& Ladeira 2017) near to the BES II lithic site. This area is inserted into a geomorphological context (figures 6 to 11 and table 1) with soft local vertical variations that do not exceed $30 \mathrm{~m}$ (and usually contained between an altitude of $480 \mathrm{~m}$, actual Jacaré-Guaçu river level, and $510 \mathrm{~m}$, on the limit of the low terraces and smoothed slopes and intermediate terraces). Inclinations are also relatively shallow in most of the area, hardly exceeding $5 \%$ on terraces and $10 \%$ on slopes (Cheliz 2015, Cheliz \& Ladeira 2017).

On the left margin (located to the south of the Jacaré-Guaçu river), the flood plains are wider and border low terraces a $(485-490 \mathrm{~m})$, and low terraces b (490-510 m) - figures 6 and 11 .

On the right margin (located to the north), the floodplains are sometimes five times smaller than those on the left margin and often border intermediate terraces and even slopes.

The asymmetric character of the floodplains of the Jacaré-Guaçu are also seen in its surroundings, for instance, the Boa Esperança do Sul river (about some kilometers south of the course of Jacaré-Guaçu river), also showing left margins significantly wider than right margins (Cheliz 2016).

The asymmetry recorded in the alluvial plain is also recorded in the slopes (figure 6). On the right bank of the plain, the slopes are associated with significantly higher inclinations (figure 6) than on the left margin. The altimetric increments from their limits in the right margin are also pronounced, reaching the quota of $680 \mathrm{~m}$ and the compartment of Highlands and Residual Plateaus between $15 \mathrm{~km}$ in horizontal extensions of the said margin. Regarding transects perpendicular to its left margin, it would be necessary to cover more than $40 \mathrm{~km}$ in horizontal extensions before reaching similar relief levels (Residual Plateau of Dourado).

In the surroundings of the low terraces where the BES II site is located, there are numerous abandoned meanders (figures 6 and 8) - some of them (type I meanders) exhibiting paleochannels with width dimensions and symmetry axes significantly larger than those registered in the current Jacaré-Guaçu channel. Others (abandoned meanders of type II) present attributes similar to the 
current course of Jacaré-Guaçu river (Cheliz 2010, 2013, 2016).

The five pedosequeces (figures 6 and 7) superimposed on the BES II site are aligned across the boundary between some of the relief units present in the study area (Flood Plains and Low Terraces a - individualized in Low Terraces Ia and IIa on the pedosequence area) on the left margin of the Jacaré-Guaçu river.

The morphometric variations of the five topographic profiles correlated to the pedosequeces converge when they indicate a relatively low altimetric and clinographic increment, as it moves away from the Flood Plains and enters the Lower Terraces.
Most of the descriptions of soils are of sand-clay or clayey texture. The presence of highly tacky organic clay is noted in some of the surveys adjacent to the flood plains.

Among the horizons present in the pedosequeces, those of greater vertical and horizontal extension are the A and $\mathrm{C}$ horizons.

As shown in more detail in Cheliz \& Ladeira (2017), the A horizon is associated with colors that usually alternate between 7.5 YR 4/2 and 7.5 YR 5/4 in the Munsell Soil Color Chart, being usually sandy, slightly plastic and not very sticky.

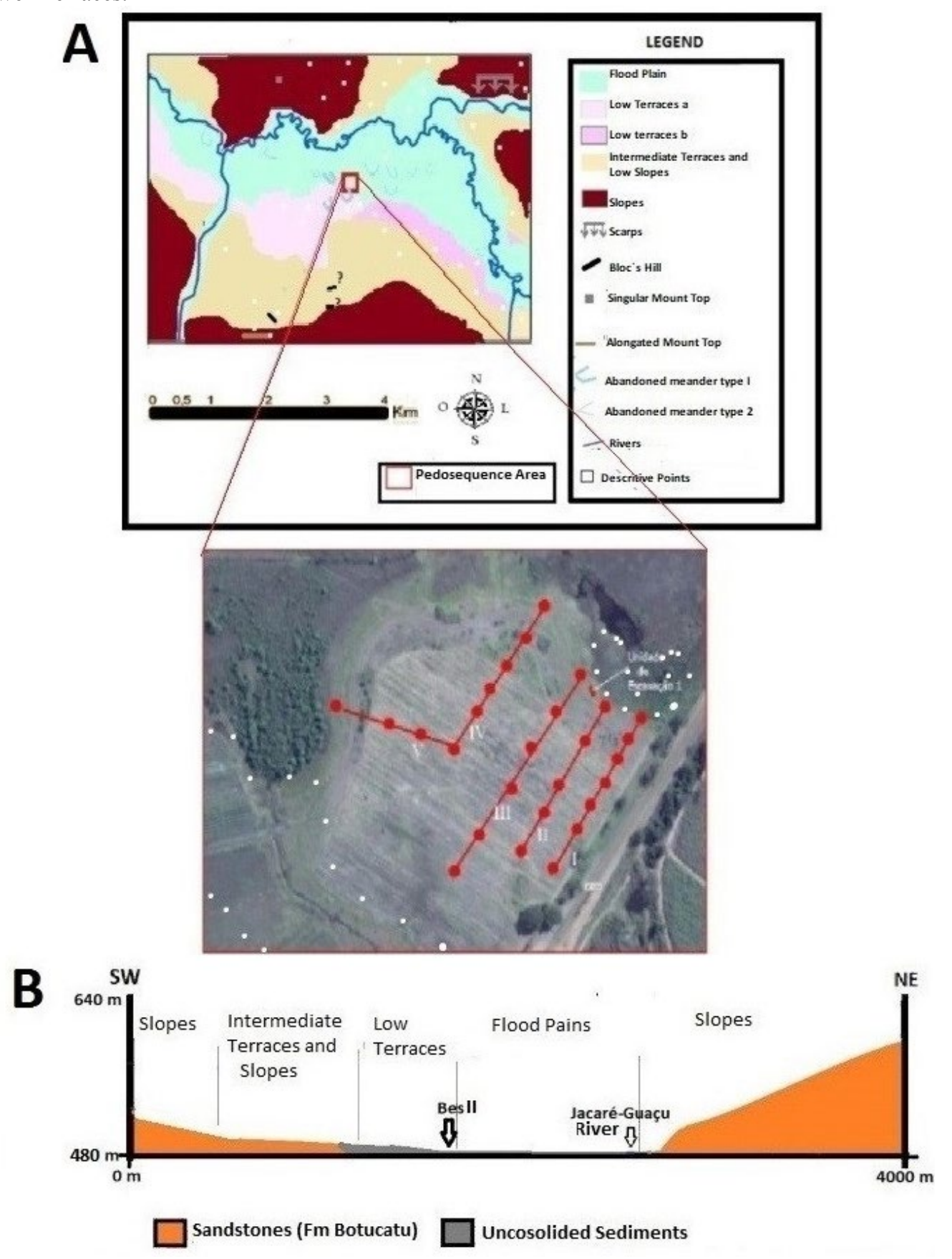

Figure 6: (a) Detail Relief Compartmentalization of a lowland segment of Jacaré- Guaçu, local chosen for pedosequeces and (b) SW-NE profile of the area. Source: Cheliz (2016) 
Horizon $\mathrm{C}$ exhibits colors that fluctuate predominantly between 7.5 YR 5.5 / 6 to 7.5 YR 7/6, alternating between slightly plastic and slightly sticky segments (usually when near or below the water level).

It is not possible to discriminate a B horizon in any of the points analyzed, since the A horizon is generally superimposed directly onto the $\mathrm{C}$ horizon. Indications of mottling (colors close to $2.5 \mathrm{YR} 5 / 8$ ) were sparse between profiles and especially present in the $\mathrm{C}$ horizon.

The set of surveys documented intense gleying present at both the superficial and deep levels of all pedosequeces analyzed, corroborating previous works (Cheliz 2010, 2012, 2013, 2015, 2016, Cheliz \& Oliveira 2011).

The extent of gleying is such that the soils of all the points covered by the five pedosequeces can be classified as Gleysols (Embrapa 2006), even those located at higher altitudes and greater distances from the current flood plains. Gleysols are hydromorphic soils, usually developed by the alteration of unconsolidated sediments and bound in a prolonged saturation by water which binds the reduction and solubilization of iron. They usually occur in areas of small inclinations (Embrapa 2006), although in the Low Terraces IIa they have a relatively significant inclinations, and can reach thicknesses of more than $2 \mathrm{~m}$.

In fact, if it was not for the Gleysols, the Low Terraces IIa could be marked by slopes due their greater altitude and degree of inclination that those from the Low Terraces Ia.
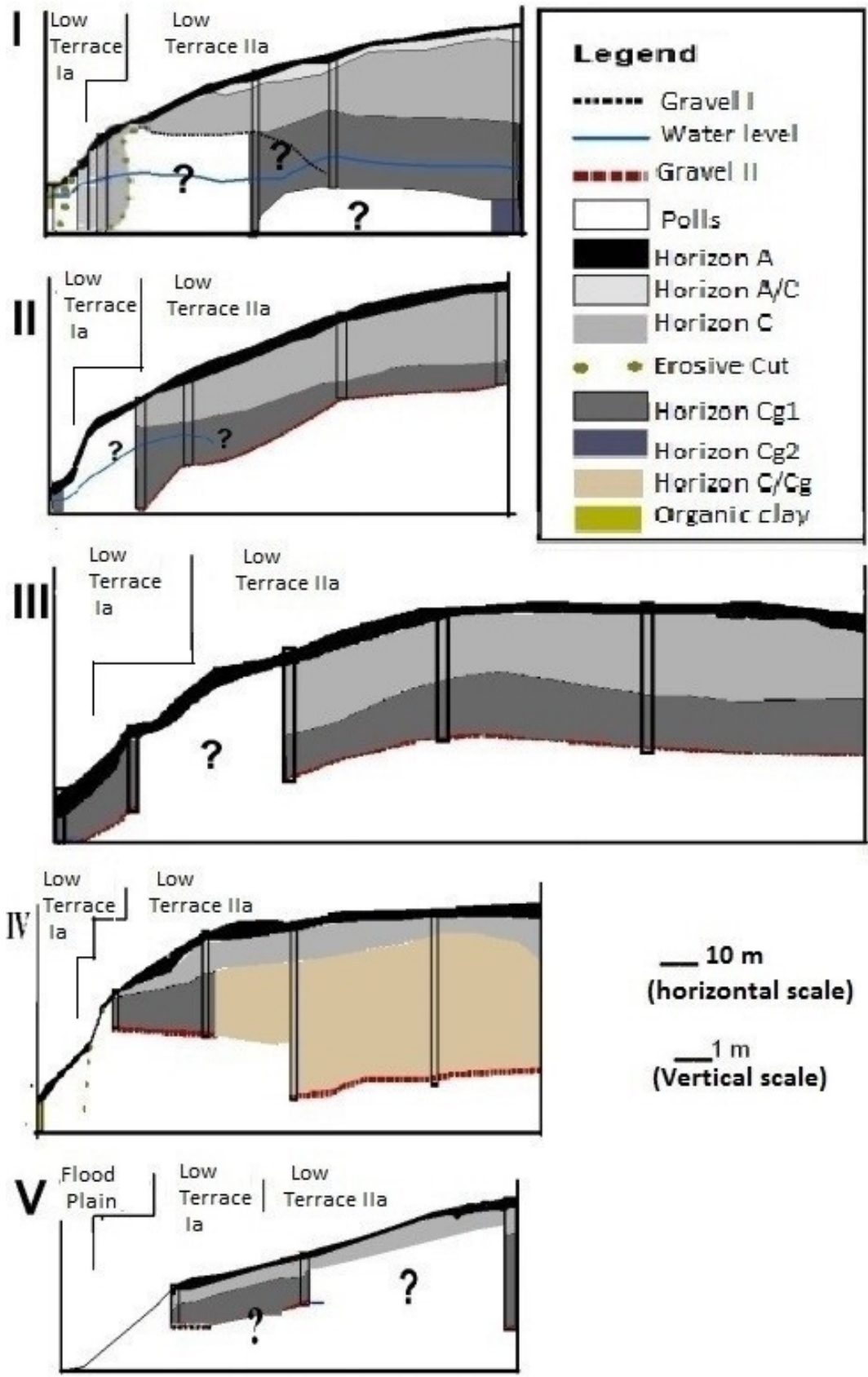

Figure 7: Pedosequences of Jacaré-Guaçu River low terraces (left bank) whose location (indicated by the Roman numbers) is shown in the figure 6. Source: adapted from Cheliz (2016) 

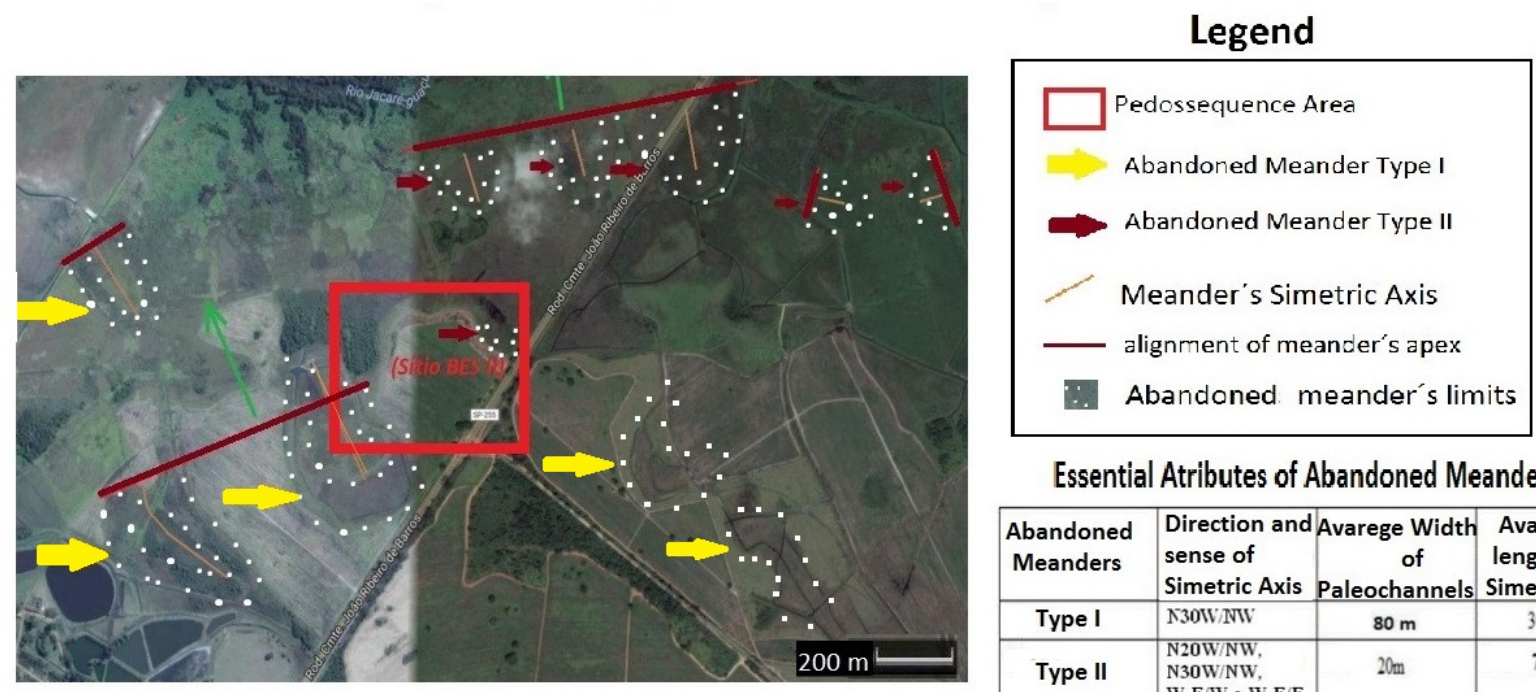

Essential Atributes of Abandoned Meanders
\begin{tabular}{|c|l|c|c|}
\hline $\begin{array}{c}\text { Abandoned } \\
\text { Meanders }\end{array}$ & $\begin{array}{l}\text { Direction and Avarege Width } \\
\text { sense of } \\
\text { Simetric Axis }\end{array}$ & $\begin{array}{c}\text { Avarege } \\
\text { of } \\
\text { length of } \\
\text { Saleochannels } \\
\text { Simetric Axis }\end{array}$ \\
\hline Type I & N30WWNWW & $\mathbf{8 0 ~ m}$ & $300 \mathrm{~m}$ \\
\hline Type II & $\begin{array}{l}\text { N20W/NW, } \\
\text { N30W/NW, } \\
\text { W-E/W e W-E/E }\end{array}$ & $20 \mathrm{~m}$ & $70 \mathrm{~m}$ \\
\hline
\end{tabular}

Figure 8: BES II site Jacaré-Guaçu River alluvial plain surroundings with paleochannels of abandoned meanders of type I, with plant widths and symmetry axes much wider than the current Jacaré-Guaçu, and type II - with patterns similar to those of the contemporary Jacaré-Guaçu river. Observe parallels of the apexes of the meanders and symmetry axes (N20W-N30W predominating), supporting lateral migration path near the south-north of the channel after abandonment of the Lower Terraces IIa and in the new floodplain, after abandoning the low terraces Ia where concentrates parts of the BES II site. Source: adapted from Cheliz (2016).

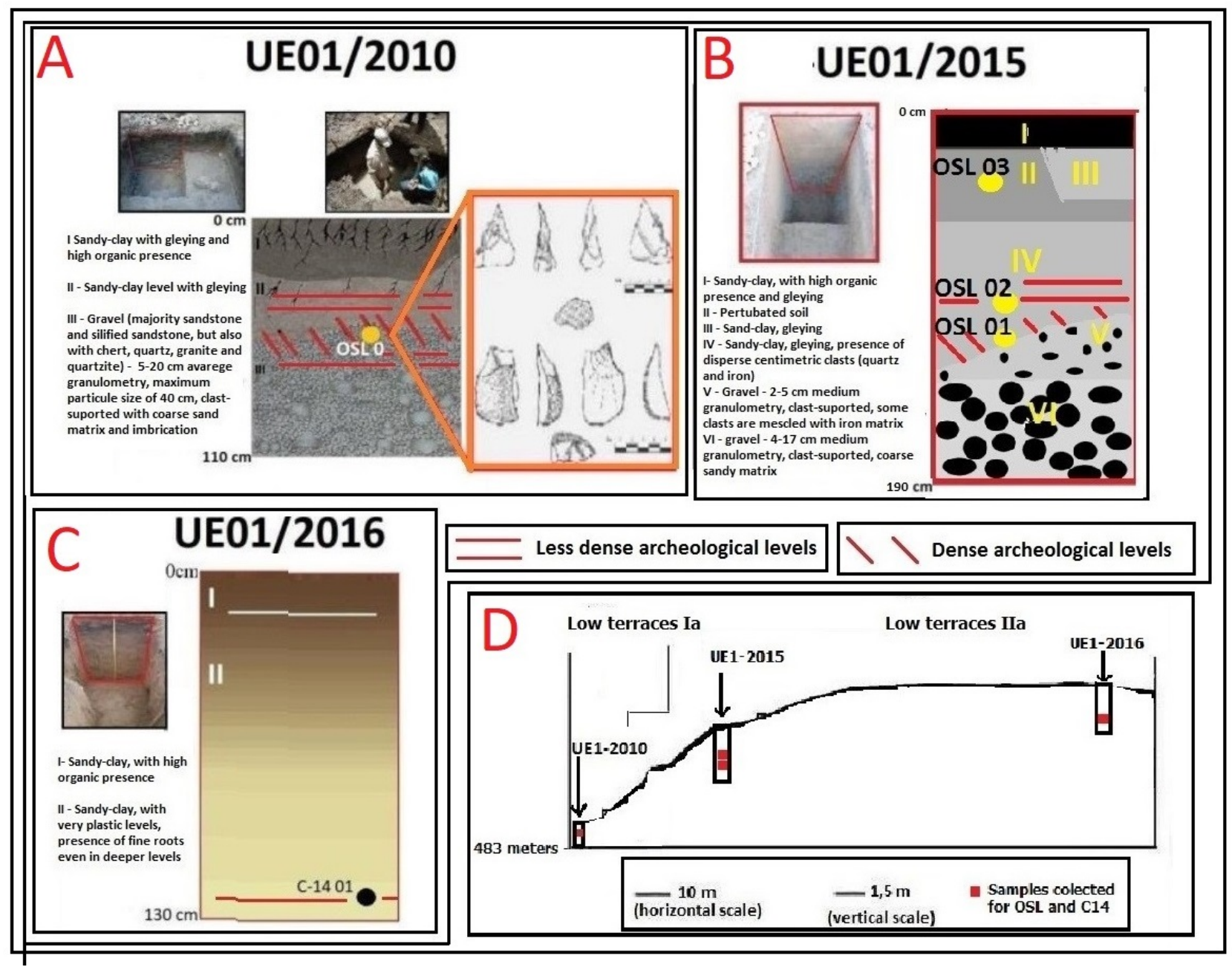

Figure 9: (A) profile of excavation unit of 2010 on low terraces Ia and position of sample collected for OSL, (B) profile of excavation unit of 2015 on low terraces IIa and positions of samples collected for OSL analyses, (C) profile of excavation unit of 2016 on low terraces IIa, and local of samples colletcted for 14-Carbon analyses, (D) excavations units distribution on morphologic profile of low terraces (same of pedosequence III). 
Table 1: Geochronological data from Low terraces of Jacaré-Guaçu River

\begin{tabular}{lllll}
\hline Sample & Deep $(\mathbf{c m})$ & Material and Method & Age (1000 years BP) & Observations \\
\hline OSL 0 & $50-60$ & Sediment/Soil, OSL & $14.5 \pm 3.0$ & $\begin{array}{l}\text { Very dense archaeological level - about 200 } \\
\text { pieces (Santos 2011; Santos \& Cheliz 2017) }\end{array}$ \\
\hline OSL 01 & $110-120$ & Sediment/Soil, OSL & $10.9 \pm 1.16$ & Dense archaeological level \\
\hline OSL 02 & $90-100$ & Sediment/Soil, OSL & $4.09 \pm 0.34$ & Less dense archaeological level \\
\hline C14 01 & $120-130$ & Charcoal, ${ }^{14} \mathrm{C}$ & 8.85 to 8.35 (calibrated age) & $\begin{array}{l}\text { Less dense archaeological level, with chert } \\
\text { piece with thermal alteration register }\end{array}$ \\
\hline Sorer & & &
\end{tabular}

Source: adapted from Cheliz et al. (2018). OSL dates from FATEC (OSL 0) and Luminescence Dating Laboratory of University of Washington (OSL 01 - laboratory number UW3522 - and OSL 02 - laboratory number UW3523, analyses done by James Feathers), ${ }^{14} \mathrm{C}$ date from Beta Analytic. Location of the samples as show in figure 9 .
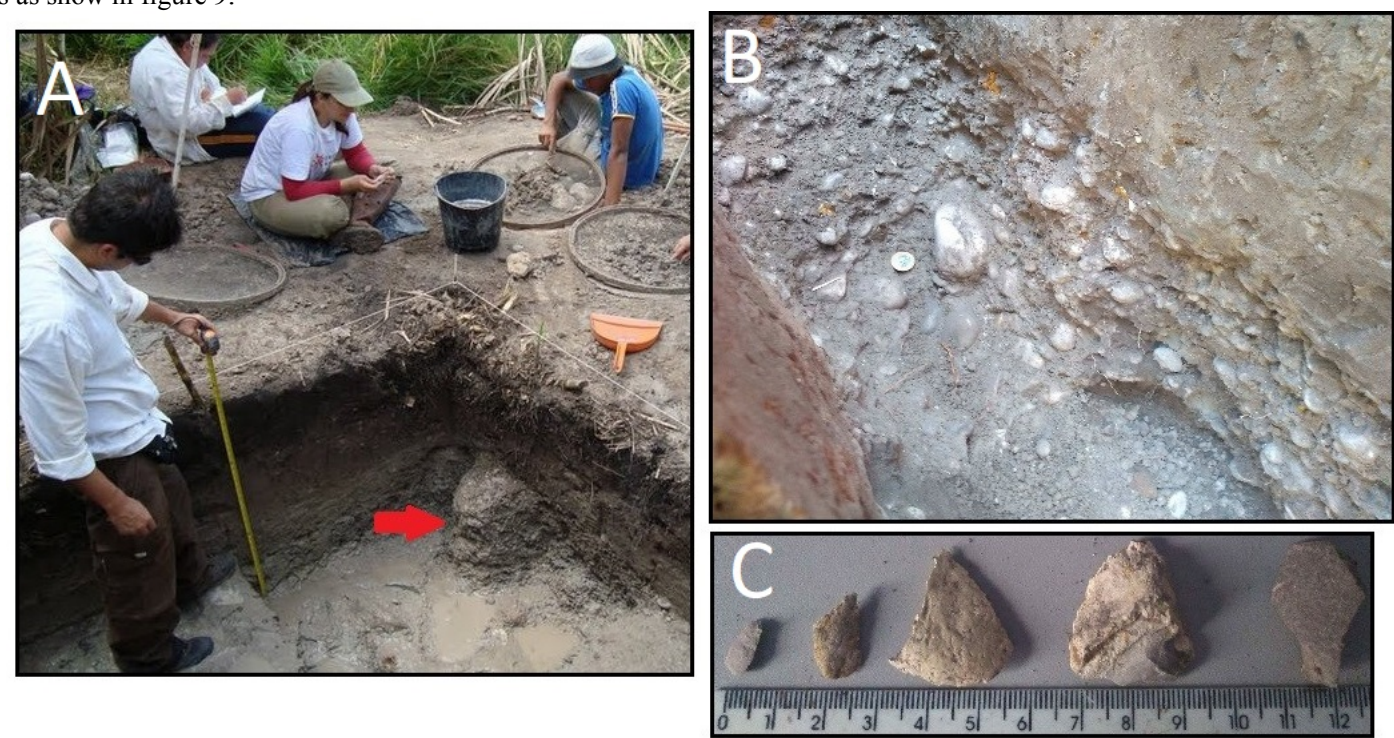

Figure 10: (A) UE1-2010, with highlight (red arrow) for one of the largest basal gravel clasts, (B) closer view for basal gravel level (UE1-2019), (C) some chert and sandstone archaeologic artifacts found near the limit between the basal gravel level and the sandy-clay sediments under gleying (UE1-2019). Source: Photo A Fabio dos Santos Grossi.
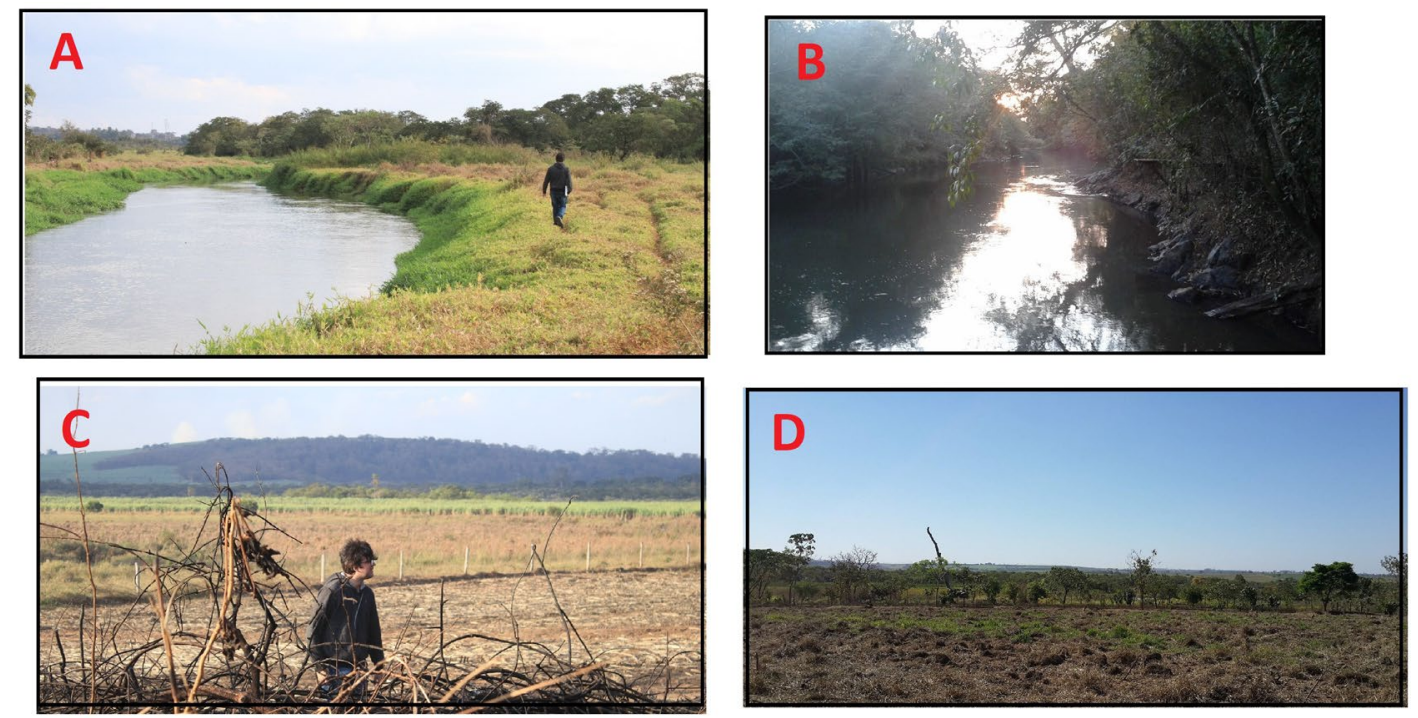

Figure 11: Composition of photos of the detail area: (A) Jacaré-Guaçu river and flood plains on the right margin of Jacaré-Guaçu River, on the segment with larger alluvial plain next to the W-E course of the river. (B) Jacaré-Guaçu river and slops, on the segment with NE-SW course of Jacaré-Guaçu river (C) Low terraces b (D) Low terraces a. Note that that terrain bordering the river on the right bank shows inclinations greater than left on both A and B photos. Source: Photos A and C Wisley Luiz.

Two types of gravels are also observed throughout the surveys. One of them - type 1 gravel - is composed of fine gravel levels (quartz and iron gravels between 1 and $4 \mathrm{~cm}$ ) which were unable to prevent the continuation of perforations.
The other gravel type (type 2) presents characteristics that made it impossible to continue the surveys, and which usually marks the end of the auger with iron oxides. 
These type 2 gravels reminded us of conglomeratic units (figures 9 and 10) that guided previous work (Zanettini Arqueologia 2003) in the area, such as the Excavation Unit (UE) 01-2010 (figure 9), linked to the work of Santos (2011) and described in Cheliz (2010, 2012, 2015). In this excavation unit, approximately 500 lithic artifacts are concentrated, mostly within the first $30 \mathrm{~cm}$ of the conglomeratic level. It is located near the initial stretch of pedosequence 3 (figures 7 and 9). They are also similar to conglomeratic basal units seen in UE01-2015 and UE02-2017, but are not found in UE1-2016 in the Low Terrace 2a (figure 9).

Excavation unit 01-2010, first described in Santos (2011), Cheliz (2010, 2012) and Cheliz \& Oliveira (2011), and the base for the the pedological descriptions in Cheliz $(2011,2015,2016)$ and Santos \& Cheliz (2017) is a $2 \mathrm{~m}$ wide, $2 \mathrm{~m}$ long, $1.13 \mathrm{~m}$ deep trench excavated in the Low Terraces Ia, next to the limit with of the floodplains (figure 11). The basal level is marked by the presence of well-rounded gravel (with predominance of flint and sandstones with concentric iron alteration levels), imbrication and is covered by sandy-loamy levels with expressive gleying.

A similar pattern was also observed in units UE01-2015, UE1-2016 and UE01-2017 during fieldwork with Rodrigues, Araújo, Santos and Ladeira, and in unit UE01-2016 during fieldwork of Araújo and Santos, who authorized the results to be shared (figure 9) and approached in the geomorphological context. OSL data were available for UE1-2010 and UE1-2015, and a C-14 date for UE01-2016. OSL from archaeologic levels gave a measure of $14,500 \pm 3,000$ years BP (gravel level of UE01-2010) to 10,900 and 4090 years BP (UE1-2015, sandy clay levels that cover the gravel). The ${ }^{14} \mathrm{C}$ data from UE01-2016 (sandy-clay covers) archaeologic level gave a calibrated age near to 8630 years BP (figure 9).

\subsection{Discussion (detail level)}

The basal gravels recorded in excavation unit I of the Low Terraces may be a good starting point for discussion. The imbrication and the degree of rounding of these basal gravels suggest that they could be river pebbles. These have a significant degree of similarity to deposits associated with ephemeris torrential channels (Goudie 2013), with the mean width of the pebbles $(5-20 \mathrm{~cm})$ being significantly bigger than actual pebbles $(2-5 \mathrm{~cm})$ from the Jacaré-Guaçu river.

The presence of torrential channels could be specifically related to the transition between semi-arid to higher humidity patterns in the Pleistocene and Holocene transition to vast areas in Center-South Brazil - as exemplified by Almeida (1964) and Ab'Saber (1998).

The sandy-clay and clayey-sand that cover the basal sandstone clasts can in turn be interpreted at least partially as deposits of old alluvial-plains, which would later have been exposed to processes linked to gleying. Subsequently, terracing and the continuity of the gleying by surface segments over a $100 \mathrm{~m}$ in extension indicate the abandonment of the old plain and deepening of the riverbed.

The set of environmental oscillations agrees with known regional fluvial dynamics, described in the works of Celarino et al. (2013) and Souza (2010) for terraces of the Mogi-Guaçu River located some tens of kilometers northeast of the study area and subsequently correlated in Cheliz \& Oliveira (2011) and Cheliz (2011, 2012, 2015).

These studies indicate a significant change in the baseline levels of hydrographic systems near study area, and abandonment of the old flood plains at some point after 10,000 years BP. The data cited in the literature are compatible with those collected in the Jacaré-Guaçu terraces in the study area, which converge to suggest a deepening of the channel bed around the Holocene.

The association of the dates, the context of the surface cover and the archaeological material allows us to consider the idea of including the BES II site within the set of archaeologic site belonging to the Pleistocene-Holocene transition (13000 to 8000 years $\mathrm{BP})$. In the case of BES II, several factors contribute to suggest a fit between the date obtained and the physical environment. As pointed out, the OSL sample was extracted from a level that with hundreds of artifacts distributed in a restricted horizontal $(1 \times 1 \mathrm{~m})$ and vertical $(0.3 \mathrm{~cm})$ range from the gravel level.

In this vein, it is appropriate to note the OSL measurement of $14,500 \pm 3,000$ years BP in a gravel level with the presence of archaeological artifacts. The sample sent for dating was collected from the segment next to the limit between the deposit of basal clasts and the sandy gleysoils that cover it. It is also in this segment that most of the approximately 500 archaeological pieces - predominantly sandstone and chert flakes are found in the excavation unit (Santos 2011, Santos \& Cheliz 2017).

It would be difficult to suggest a process of bioturbation or erosive action that could select, amidst the diversity and abundance of available lithological material, precisely those of archaeological significance and concentrate them in such a narrow vertical and horizontal band.

In analyzing the vertical distribution of the pieces of the BES II site, it can even be suggested that the ancient human hunter-gatherer groups employed the basal fluvial pebbles as a source of raw material for the chipping of their tools. It would be possible to consider that local human groups would have taken advantage of geomorphological changes and attributes derived from the change to more humidity climate patterns conditions in the Pleistocene-Holocene transition.

The gravels exposed after exhaustion of the torrential channels would be an exceptional attraction for groups of hunters and gatherers, as they would be an expressive source of raw material for the tools and artifacts necessary for their survival. It is recalled that rock outcrops are very uncommon in the study area, especially due to reduced regional declivity and the spread of deep soil horizons. We suggest that the 
concentration of gravels, when exposed, would thus have been sufficient for nomadic or semi-nomadic human groups to periodically return to this location. It should be noted, however, that the said excavations units in the Low Terraces Ia on which these observations are centered is not the only subsurface archaeological record referring to the site. There is also a series of surveys in the surrounding low Terraces IIa, linked to the work of preventive archaeology of the company Zanettini Arqueologia (2003), and another excavations units like UE1-2016. These clusters present archaeological material not associated with the transition between deposits of basal clasts and arenaceous gleysols, and even near surface levels. They would allow to estimate a chapter of the history of local occupation differentiated to the punctual records of the Low Terraces analyzed here.

One possible explanation would be that both the gravels of the Excavation Unit 0I-2010 in the Lower Terraces Ia and at least some of the type 2 top gravels (from the pedosequeces) present in the Lower Terraces IIa and Ia pre-date the two sets of Lower Terraces.

In this interpretation, the gravels would be interpreted as part of a single paleosurface, formed in a concomitant depositional process of the same type (ephemeral channels resembling semiarid exposed to crescent torrential rains).

After their deposition, the local base level would have risen by between 5 and $10 \mathrm{~m}$, linked to the alluvial plain of the paleochannel associated to the abandoned type I meander present in the Lower Terraces IIa.

In this new base level, based on transition to a climatic and hydrological regime of different conditions from the previous one and also different from the current one (figure 9) the alluvial plain would form and deposit at least some of the sets of sandy-clayey sediments. The aforementioned deposits would undergo gleying processes due to periodic floods, and would result in the Gleysols of the Lower Terraces a.

This approach corroborates the radiocarbon date from UE1-2016 of the archaeological level near the top of pedosequence $\mathrm{V}$, also next to the paleochannel of the abandoned type I meander adjacent to the pedosequeces in the Low Terraces IIa, which have age around 8800 years BP. This age is later than the date of $14,500 \pm$ 3000 years BP obtained by Santos (2011) in the UE1-2010, associated to the ephemeral and torrential basal gravel levels, and later than the date of 10,900 \pm 1500 BP obtained on the deep sandy deposits near the upper limit of the basal gravel in UE1-2015 (figure 9).

After this episode of the base-level ascension (that would endure at least until the Early Holocene, as seen the C-14 data in UE1-2016, figure 9), there would be an episode of a fall of magnitude similar of the previous rise, leading to the abandonment of the old alluvial plain system and the formation of the Lower Terraces IIa and Ia. In the transition between basal levels, the erosion of the Lower Terraces a would be intense.

Periodic flooding of the floodplains would cut off the sandy convers of Lower Terraces IIa, and also perhaps the gravel level during moments of greatest erosive stress. In this sense, pedosequence I shows at least two erosional lateral cuts next to a current type 2 meander that cuts the boundary between the flood plains and Low Terraces Ia, a possible current example of the way that these lateral erosional cuts detected in the pedosequeces in the limits between Low Terraces Ia and IIa were made in the past.

Subsequently, there would have been a further decrease of the base level (more discrete, of the order of $1 \mathrm{~m}$ ) in search of the topographic level of the current channel of the Jacaré-Guaçu river, and migration to north of the channel associated with the transition, linked also to some hydrologic and climatic changes, as indicated by the differences between the paleochannels of the abandoned Type I meanders present in the Lower Terraces IIa and the Type II meanders present in the floodplain, which are more similar to those of the current channels.

Lateral migration that could have passed through accentuated punctual activities linked to neotectonic processes of the Araraquara area, partially concomitant and possibly related to the possibility of tipping linked to structural process on the area. As it makes possible to interpret from the parallelism of the axes of abandoned meanders I and II, from the asymmetrical pattern of the alluvial plain (much wider on the left river bank, south, than on the right river bank, north), among other elements.

In the whole process, there would be a local incision of the base level of at least $7 \mathrm{~m}$ during the Early Holocene-Late Holocene interval (during the last 8800 years, as shown by the vertical range between the top of UE1-2016 and today day Jacaré-Guaçu river, figure 9 and table 1), and of at least $3 \mathrm{~m}$ at the Late Holocene (during the last 4000 years, as shown by the vertical range between the top of UE1-2015 unit and today day Jacaré-Guaçu river, figure 9 and table 1).

This interpretative option allows a reconciliation of chronomorphological successions linked to more traditional paleoclimatological interpretation (Haffer 1969), and knowledge of the same successions on a regional scale (Celarino 2011, Sousa et al. 2013). It is possible to suggest the existence of regional controls for the alternations of basal levels close to the Pleistocene-Holocene transition (Cheliz 2012, 2015).

It should be noted that the interpretive possibilities of geomorphological successions are presented only as suggestions for the explanation of the field data. It is necessary to intensify studies in order to weigh them up properly. Particularly, it would be necessary to open new excavation units in the middle of the Lower Terraces IIa and Ia to better characterize the gravels.

It would also be necessary to increase the density of pedosequence points to perform data interrelations with greater security. It should be noted, however, that in the geomorphological sequence suggested to explain the field data, the dating attributed to the Boa Esperança II site by Santos (2011) is adequate in the context of the surface structure. If it were not for the presence of 
archaeological material, the geomorphological and environmental changes in question could be correlated without major controversy to the relatively similar tables pointed to transition between proximal to semi-arid conditions for others of more humids patterns recorded in the Pleistocene-Holocene transition in the literature.

\section{Conclusion}

We were able to delimit three large sets of relief macro-partitions - Residual Plateau, Transitional Levels and Lowlands of ancient Araraquara - and to present their morphometric and lithological features, aiming to relate relief patterns of Araraquara area with lithic archaeological sites.

As well, as describe general attributes of the characterization and distribution of relief forms, we could overlap lithic archaeological sites to relief partitions and identify possible associations.

We found that archaeological sites are associated predominantly with the Transitional Levels compartment, and attempt to explain why this might be. Sites upon the slopes of the Transitional Levels emerged at a time when it is not possible to determine if essential relief delineation had already occurred or was still in progress.

We also discussed attributes of the different compartments that could help explain certain features of archaeological sites, especially highlighting the different availability of lithic raw materials as a potential factor.

By integrating analysis of the available data over different scales, and focusing on the delimited portion of the Lowlands of Jacaré-Guaçu Late Pleistocene-Holocene interval around the BES II site, we can list the estimated geomorphological and environmental changes of the area along time and their relation to known archaeology. Such sequences are of preliminary character and represent an early attempt to explain the field data, subject to refinements with future research:

(I) Alternations between lateral formation of flat levels and vertical incision, occasionally intensified by possible faults (N-S, N70E, N80W) of restricted horizontal extensions and diversified tailings, are presented as geomorphological mechanisms in the post-Cretaceous for the Araraquara area. The essential morphological contrasts of the area are marked by different lithotype resistivity to the alternation of previously mentioned processes. Age of faults are difficult to determine. Presence of outcrops due to larger inclinations of the terrain would lead to the attraction and concentration of archaeological sites adjacent to fault escarpments, and it is not possible with the available data to state whether their implantation would be relatively concomitant to deformations or significantly later. We did not find enough elements to be able to discuss the possible cause of the aforementioned geomorphological oscillations before the Late Pleistocene, since the semi-detailed data we collected did not allow a clear distinction to be made between processes possibly linked to structural dynamics and those linked to climatic dynamics. It is possible, however, that products of deformational activities merged to the alternation between the chronological sequences previously mentioned, leading at least to intensification of vertical incision dynamics and formation of sectors with more intense slopes in some of the areas.

(II) The most well-preserved manifestations of Quaternary geomorphological alternations are found in the Lowlands of the Jacaré-Guaçu in the surroundings of the BES II site (detail area), related to the record of migration of the Jacaré-Guaçu river axis to the north (as show by the asymmetric patterns of relief in the Boa Esperança Morrarias - Cheliz 2016 - and by asymmetric extensions and inclinations of slopes, terraces and floodplains on the left and right margins of the Jacaré-Guaçu and Boa Esperança rivers). It is possible that neotectonic could have influenced the migration of the rivers to north. The asymmetry of the lateral extension of the alluvial plain and the wide thickness of the deposits of the low terraces a could also have a influence of neotectonic. Rupture deformation processes, with faults of relatively discrete tailings near $\mathrm{N}-\mathrm{S}$ direction placed to the east and west of BES II is presented as a possibility. A lowering of the block combined with presence of basalts to the west would help to explain the large lateral extension of the alluvial plain (the majority of which occurs on the W-E course of the river, and is not present in the NW-SE course of the detail area). The meandering and near-embedded pattern of segments of the basaltic western segment would combine in the same direction (presence of various estimated fault planes NW-SE, N-S with rivers embedded in tributary streams and Jacaré-Guaçu river, on its right banks in the western segment of the area perpendicular to the axis of the Jacaré-Guaçu river).

It should be also noted that rectilinear drainage anomalies that flow on basalts of this section of the Jacaré-Guaçu River are also aligned with the N-S direction of the embedded rivers of the adjacent Transitional Levels.

(III) Prevalence of semiarid conditions in the terminal Pleistocene. Fluctuations of semiarid conditions and the increase of humid conditions, with a transitional period marked by torrential rains, would lead to the formation of ephemeral torrential channels (Goudie 2013, Ab'Saber 1998) between the Late Pleistocene and Early Holocene (gravel type II, and basal gravel from Jacaré-Guaçu river low terraces a of BES II site). The availability of sandstone and chert gravels would have been evidently attractive for human occupation within a context of relative scarcity of raw materials, helping to explain why the higher concentration of archaeological artifacts in the vertical profiles is associated with the upper limits of the basal gravel, with artefacts of restricted retouching and limited incidence of cortex due to size of clast. 
(IV) Elevation of the base level (5 to $10 \mathrm{~m}$ ) by undifferentiated causes, but possibly by a combination of structural and neotectonic factors (the lowering of the block that nowadays hosts the wide alluvial plains of the Jacaré-Guaçu) and climatic factors. Formation of sandy-clay and clayey-sand alluvial plain deposits linked to abandoned type 1 meanders, with channels of different (perennial) patterns than-previous, but also but also different-than-present hydrological conditions (although already ruled by climatic conditions of greater precipitations than those of the previous semiarid pattern). Archaeological artifacts are still recorded in these sandy-clay layers, signaling continuity of human presence, but they are present in a significantly different quantity and density, and show more frequent retouching - instruments with all retouched edges are recorded, and less retouched edges seem to be less common (Zanettini Arqueologia 2003, Santos 2011). This period was possibly marked by a decrease in the availability of raw materials as the basal pebbles were covered by sands of the alluvial plain and became less accessible, which may have led to a reduction in lithic production and a shift in the technology towards greater tool re-use.

(V) Reduction of the base level $(5-9 \mathrm{~m})$ and the formation of a new level of terrace (IIa). Possible erosion of part of the then-exposed archaeological material which were remobilized and re-deposited (along floodplains?) with sediments and soils. Tributaries embedded even at reduced altitude (just over $490 \mathrm{~m}$, surrounded by abrupt slopes and vertical ruptures of up to more than $5 \mathrm{~m}$ ) from the right bank of the Jacaré-Guaçu (Cheliz 2016) - from springs located tens of kilometers to the northeast - would precede the processes of lowering of the base level where the alluvial plains near the BES II site are placed today, adapting to it and expressing it in its asymmetrically inclined slopes today. Parallel tributaries of the left bank at similar altitudes, but with slopes of relatively small declivity and nearby springs, would possibly be posterior to this process

(VI) A new, smaller reduction of the base level, (order of $1 \mathrm{~m})$. Formation of Low Terraces Ia.

(VII) Intense lateral migration (at least $500 \mathrm{~m}$ ) towards the right margin, as seen by the settling of the river channel closer to the right (north) than to the left (south) margin, to form dozens of abandoned meanders (type II) on the left margin. Main control would not be of lithological origin, since the pattern repeats in parallel streams to the south (Boa Esperança do Sul river Cheliz 2016) with both margins of sandstones. It is possible that this pattern is a response to regional neotectonic processes, such as those observed with a clearer record in the northern portion of the study area (near the city of Santa Lucia - Cheliz 2016). Lateral migration would obliterate most of the low terraces on the right banks, as seen by the present-day Jacaré-Guaçu river channel, which crosses intermediate terraces or even slopes. Migration would take place in hydrological conditions already closer to the present, since the widths of the channels of the abandoned type II floodplain meanders are similar to the one of the current channels.

(VIII) Historic avulsion dynamics would lead segments of the river - especially in the mouths of tributaries - to move slightly away from the border of the right margin.

To summarize, referring to the specific point of the relationship between archaeological materials and geomorphologic data - we noticed that those (Galhardo 2010, Santos 2011) located on lowland fluvial terraces are an exception to the rule $(n=2)$ in Araraquara area, since the majority are present in the Transitional Levels. However, the site with the largest number of lithic pieces dating to the Pleistocene-Holocene Transition (BES II site) falls within the aforementioned typology of interface exception with relief frames.

We discuss the possibility that human occupation of the site emerged with the record of suggested proximal geomorphological sequences placed between Last Pleistocene and Middle Holocene. The vertical and horizontal position of the archaeological record of the BES II site suggests its inclusion in sets of attributes of geomorphological and environmental changes traditionally associated with the return of humid conditions that, for researchers like Ab'Saber (1998), marked the Pleistocene-Holocene transition in several places of Central-south Brazil. Observations show that the landscape transformations recorded in the area are similar to those demonstrated during the Pleistocene-Holocene transition by previous works in segments relatively close to the study area, in the Mogi-Guaçu valley bottom (Celarino 2011).

However, it should be noted that the acceptance of the date of the relief frames adjacent to the BES II site as close to the Pleistocene-Holocene transition must be cautious, especially due to the implication for understanding the scenarios of past human occupation. It is briefly observed that one of the striking features of the dating of the BES II site is the distinction of its analysis from the perspective of the geomorphogenic dynamics and the perspective of the archaeological study. Data presented here show that insertion of the ages associated with the BES II site considering only the context of the known relief sequences and environmental transformations seems far from causing great controversy. It is also possible, through data from the physical and archaeologic records, that human occupation is merging with successions of different combinations of environmental, climatic and geomorphological conditions. Diverse temporal analyses can be superimposed by incorporating vestiges and rhythms of human transformations and geomorphological frameworks, and demand both the diversification and intensification of studies to arrive at adequate conclusions.

\section{Acknowledgements}

We acknowledge Astolfo Araújo for including fieldwork of this article in his Paleoindian Project and for allowing to be included in his IPHAN permit to work 
at the archaeological site (2015 and 2016 field work). We also acknowledge Astolfo Araújo for sending the samples of 2015 and 2016 fieldworks to OSL and radiocarbon dating, and authorize us to share the results and contextualize them in the geomorphologic context. We acknowledge James Feathers (University of Ohio) for the analyses of OSL. We acknowledge Fabio Grossi dos Santos and Robson Antonio Rodrigues for the Iphan permit to work at the archaeological site (2010, 2017 and 2019 field works). We acknowledge Leticia Ribeiro, Dulcelaine Lopes, Louise Prado, Diego Fleming, Robson Rodrigues, Astolfo Araújo, Fabio Grossi Santos, Nathalia Carvalho, Adriana Saraiva, Stefano Gobbi, Daniele Lopes, Raquel Okano, Marcelo Delilo, João Moreno, Gabriela Sartori, Wesley, Nathalia Carvalho, Francisco Ladeira, Diego Nascimento, Everton Valézio, Clesio Santos for help during the excavation activities. We acknowledge Marcelo Delilo, Celso Graminha, Daniel Cruz Berto and Carlos Gibele for the help in the regional mapping. We acknowledge Francisco Ladeira for leading the pedological survey of the pedosequences. We acknowledge CNPQM CAPES and FAPESP (process number 13/13794-5) for the material support for this research, including research funding. We also acknowledge MAPA (Araraquara Museum of Archaeology and Paleontology), Fundação Arãpora (in the person of Robson Rodrigues).

\section{References}

Ab'Saber A.N. 1969. Um conceito de geomorfologia a serviço das pesquisas sobre o Quaternário. Geomorfologia 18:1-23.

Ab'Saber A.N. 1998. Participação das depressões periféricas e superfícies aplainadas na compartimentação do Planalto Brasileiro. Revista do Instituto Geológico 19:51-69.

Almeida F.F.M. 1964. Fundamentos geológicos do relevo paulista. Boletim do Instituto Geográfico e Geológico 41:69-263.

Araújo A.G.M., Correa L. 2016. First notice of a Paleoindian site in central São Paulo state, Brazil: Bastos Site, Dourado County. Paleoindian Archaeology 1:4-14.

Araújo A.G.M., Sousa J.C.M., Correia L.C., Okumura M.M. 2017. O sítio arqueológico Alice Boer, Rio Claro - SP. Processos de formação e novos dados cronológicos e arqueológicos. Anais do XVI Congresso Associação Brasileira do Quaternário. Peruíbe, ABEQUA.

Beltrão M.C. 1974. Datações arqueológicas mais antigas do Brasil. Anais da Academia Brasileira de Ciências 46:211-251.

Bueno L.D.M.R., Dias A.S., Steele J. 2013. The Late Pleistocene/Early Holocene archaeological record in Brazil: A geo-referenced database. Quaternary International 301:74-93.

Celarino A. 2011. Análise cronológica e pedológica de uma topossequência na Estação Ecológica de Jataí, Luis Antonio - SP: Relação entre processos pedogenéticos na vertente e na planície aluvial do rio Mogi Guaçu. Universidade Estadual de Campinas, Campinas. Master's thesis. 105p.

Celarino A., Souza M., Ladeira F., Branco F. 2013. Paleoenvironmental reconstruction of the Lower Mogi Guaçu River Basin (São Paulo State — Brazil), morphopedosedimentary records and fluvial processes. Catena, 111:80-97p

Cheliz P.M. 2010. Geoecologia do segmento oriental dos campo de Araraquara. Relatório técnico 33p.

Cheliz P.M. 2011. Implicações quaternárias da geomorfogênese de um segmento das cuestas basálticas: Aspectos geomorfológicos e arqueológicos. Anais do XIII Congresso da Associação Brasileira de Estudos do Quaternário ABEQUA. III Encontro do Quaternário Sulamericano. XIII ABEQUA Congress - The South American Quaternary: Challenges and Perspectives. ABEQUA. Búzios, ABEQUA 4p.
Cheliz P.M. 2012. Dinâmica fluvial Quaternária e influência estrutural no modelado do relevo: ponderações a partir das cuestas concêntricas. Anais do I Congresso de Geologia dos Países de Língua Portuguesa/46 Congresso Brasileiro de Geologia. S. B. d. Geologia. Santos. 1p

Cheliz P.M. 2013. Quadros ambientais e ocupação humana pretérita: bases físicas da pesquisa arqueológica em Araraquara. In: Rodrigues R.A. (org.) Compilação de atividades de 2013 da Fundação Araporã. Araraquara, Museu de Arqueologia e Paleontologia de Araraquara 20:53.

Cheliz P.M. 2015. Interface entre quadros de relevo cuestiformes e registros arqueológicos líticos: cercanias de Araraquara, nordeste paulista, São Paulo, Brasil. Meridiano - Revista de Geografía 4:135-160.

Cheliz P.M. 2016. Aspectos geomorfológicos da antiga Araraquara, com ênfase em subsídios para interface entre quadros de relevo e sítios arqueológicos líticos. Undergraduate conclusion work, Universidade Estadual de Campinas 109p.

Cheliz P.M., Ladeira F.S.B. 2017. Contextualização de aspectos geomorfológicos e da cobertura superficial do Sítio Boa Esperança II (interior paulista), como subsídio para a discussão de sua antiguidade. In: Perez Filho A., Rais A.R. (eds.) Os Desafios da Geografia Física na Fronteira do Conhecimento. Campinas, UNICAMP 6274-6288.

Cheliz P.M, Oliveira R.C. 2011. A antiguidade da presença humana em São Paulo: Uma discussão interdisciplinar. Congresso do Programa Institucional de Iniciação Científica da UNICAMP Universidade Estadual de Campinas (Edição 2011). Campinas. $1 \mathrm{p}$.

Cheliz P.M., Ladeira F.S.B., Araujo A., Santos F., Rodrigues R., Oliveira R., Feathers J. 2018. Interface entre quadros de relevo, flutuações ambientais e sítios arqueológicos líticos da Antiga Araraquara (interior de SP), com enfoque em parcela das Terras Baixas do Jacaré-Guaçu (Sítio BES II). Anais do 49 Congresso Brasileiro de Geologia. Rio de Janeiro. 15p.

Embrapa 2006. Sistema Brasileiro de Classificação de Solos: $2^{\text {a }}$ edição, Brasília.

Feathers J., Araújo A.G. 2016. Luminescense dating in Alice Boer site, Brazil. TDARCore. http://core.tdar.org/document/403549/luminescence-dating-at-ali ce-boer-site-brazil

Galhardo D. 2010. Tecnologia lítica: estudo da variabilidade em sítios líticos do nordeste do estado de São Paulo. Master's thesis, Universidade de São Paulo. 156p

Goudie A. 2013. Arid and semi-arid geomorphology. New York, Cambridge University Press. 461p.

Gigliotti M.S. 2010. Zoneamento geoambiental da região da Baixada Santista - SP como subsídio ao Uso de Ocupação de Terra. Universidade Estadual de Campinas. 158p.

Haffer J. 1969. Speciation in Amazonian forest birds. Science 165: $131-137$.

Mano M. 2006. Os campos de Araraquara: Um estudo de história indígena no interior paulista. Universidade Estadual de Campinas, Campinas 348p.

Meaulo F. 2007. Caracterização geológica, hidrogeológica e o mapeamento da vulnerabilidade natural à poluição dos aqüíferos, na escala 1:25.000, das áreas urbana e de expansão do município de Araraquara-SP. Master's thesis, Universidade Estadual Paulista. $138 \mathrm{p}$

Prous A. 1992. Arqueologia Brasileira. Editora da UNB, Brasília $613 p$.

Queiroz Neto J.P. 2002. Análise estrutural da cobertura pedológica: uma experiência de ensino e pesquisa. Revista do Departamento de Geografia da USP. São Paulo: 15(1):77-90.

Santos F.G. 2011. Sítios líticos do interior paulista: Um enfoque regional. Master's thesis. Universidade de São Paulo, São Paulo. $182 \mathrm{p}$

Schiavetto 2007. Arqueologia Regional e Educação: Propostas de Estudos sobre um "passado excluído" de Araraquara/SP. Doctoral Thesis, Universidade Estadual de Campinas. 195p

Scientia 2009. Salvamento arqueológico na área de modernização da Pequena Central Hidrelétrica Gavião Peixoto, município de Gavião Peixoto, SP. Relatório Final. São Paulo. 89p

Souza M.M. 2010. Palinologia em sedimentos quaternários, localizados na Estação do Instituto Florestal de Jataí, SP. Universidade Estadual de Campinas, Campinas 85p. 
Souza M., Branco F., Jasper A., Pessenda L. 2013. Evolução Paleoambiental Holocênica do Estado de São Paulo, Brasil. Revista Brasileira de Paleontologia 16 (2):297-308.

Troncoso L.P.S., Côrrea A.A., Zanettini P. 2016. Paleoíndios em São Paulo: nota a respeito do sítio Caetetuba, município de São Manuel, SP. Paleoindian Archaeology 1:50-71.

Zanettini Arqueologia 2003. Arqueologia. Relatório final do Programa Arqueológico Gasoduto Araraquara/ Norte - Trecho Boa Esperança do Sul - Araraquara, Estado de São Paulo. São Paulo 95p.

Recebido 26 de janeiro de 2018 Aceito 16 de dezembro de 2019 